\title{
Pengaruh Endosulfan terhadap Perubahan Histopatologi Hepar Mencit (Mus musculus)
}

\section{Effect Endosulfan on Histopathological of Liver Mice (Mus musculus)}

\author{
Wardhani, H.C.P1, Widiyatno, T. V.1, Suwanti, L.T2,3 \\ 1Departemen Patologi. Fakultas Kedokteran Hewan Universitas Airlangga, 2Departemen \\ Parasitologi, Fakultas Kedokteran Hewan Universitas Airlangga, ${ }^{3}$ Kelompok Studi \\ Toxoplamosis Institute of Tropical Disease Universitas Airlangga \\ *email: hanamoci@gmail.com
}

\begin{abstract}
ABSTRAK
Organ yang paling banyak terkontaminasi oleh paparan adalah hati, karena fungsinya sebagai adetoksifikator. Tujuan penelitian ini adalah untuk mengetahui perubahan histopatologi hati mencit (Mus musculus) akibat Endosulfan. Hewan percobaan yaitu 20 ekor mencit jantan dengan berat badan 20 gram. Paparan per-oral menggunakan Endosulfanon dengan dosis tunggal setiap perlakuan. Setelah 7 hari adaptasi, perlakuan kelompok pada hari kedelapan sebanyak 1cc per oral dengan dosis sebagai berikut: P1 $6,25 \mathrm{mg} / \mathrm{kg}$ berat badan/1cc/oral, P2 $12,5 \mathrm{mg} / \mathrm{kg}$ berat badan/1cc/oral dan P3 $25 \mathrm{mg} / \mathrm{kg}$ berat badan/1cc/oral. Pada hari kesepuluh dilakukan nekropsi untuk pengambilan hati mencit dan pembuatan mikro slide. Penelitian ini menggunakan Rancangan Acak Lengkap dengan undian. Sel hati yang mengalami inflamasi, degenerasi, dan nekrosis dihitung dengan sistem skoring. Hasil penilaian dianalisis oleh Kruska-Wallis. Jika hasil menunjukkan $\mathrm{P}<0,05$ (berbeda nyata) maka dilanjutkan Mann-Whitney. Hasil penelitian menunjukkan bahwa Endosulfan berpengaruh terhadap perubahan histopatologi hati mencit. Dosis tertinggi $25 \mathrm{mg} / \mathrm{kg}$ berat badan dapat menyebabkan keracunan dan kematian. Dosis terendah $6,25 \mathrm{mg} / \mathrm{kg}$ berat badan dapat menyebabkan inflamasi, degenerasi, dan nekrosis secara histopatologi pada hati mencit. Dosis yang lebih tinggi diberikan untuk mendapatkan tingkatan yang semakin parah pada perubahan patologisnya.
\end{abstract}

Kata kunci: Endosulfan, hati, inflamasi, degenerasi, nekrosis

\begin{abstract}
The most contaminated organ by exposure is liver, because its function as adetoxificator. The aim of this research was to find outhistopathological changes of mice liver (Musmusculus) caused by Endosulfan. Experimental animals were 20 male mice with 20 gram bodyweight. Per-oral exposure using single dose of Endosulfanon each treatment. After 7 days adaptation, group treatment on eighth day as much as 1cc per-oral with the following dose: P1 6,25mg/Kg BW/1cc/oral, P2 12,5mg/KgBW/1cc/oraland P3 $25 \mathrm{mg} / \mathrm{KgBW} / 1 \mathrm{cc} /$ oral. On the tenth day, necropsy was done to collect the liver of mice and to make the micro slide. This research using Complete Random Design with lottery. Liver cell which have inflammation, degeneration, and necrosis counted by scoring system. Scoring result analyzed by Kruska-Wallis. If the result shows $\mathrm{P}<0,05$ (significantly different) then followed by Mann-Whitney. The result of this research showed that Endosulfan takes effect on histopathological changes of mice liver. The highest dose $25 \mathrm{mg} / \mathrm{Kg} \mathrm{BW}$ may cause poisoned and death. The lowest dose $6,25 \mathrm{mg} / \mathrm{Kg}$ BB may cause inflammation, degeneration, and necrosis on histopathological of mice liver. The higher dose to be administered the more severe the pathological changer.
\end{abstract}


Keywords: Endosulfan, liver, inflamation, degeneration, necrosis

\section{PENDAHULUAN}

Populasi hama yang berkembang pesat membuat petani harus mengupayakan penyelamatan lebih untuk menjaga tanaman agar tidak dirusak atau dimakan hama, hal tersebut dapat diatasi dengan penggunaan Endosulfan. Golongan organoklorin seperti Endosulfan paling banyak digunakan karena dengan takaran sedikit dapat memberantas hama dengan cepat sehingga menghemat pemakaian (Andarini dkk., 2013). Harga pestisida yang relatif terjangkau di pasaran membuat petani merasa diuntungkan karena dapat mengurangi ataupun membunuh hama bahkan memberantas vektor penyebab penyakit (Van den Berg, 2009).

Studi kasus mengenai identifikasi penggunaan pestisida pada ladang dan sawah daerah pertanian Kecamatan Kertasari Citarun Hulu Kabupaten Bandung, didapat persentase penggunaan pestisida organoklorin masih tinggi sebesar 22,3\% (Rochmanti dan Dian, 2009). Menurut Adhiraga (2009) profil senyawa organoklorin dalam air tanah $0,986 \mu \mathrm{g} / \mathrm{L}$, air sungai $0,695 \mu \mathrm{g} / \mathrm{L}$ dan sedimen sungai $12,9 \mu \mathrm{g} / \mathrm{L}$ di Cikapundung terdapat konsentrasi senyawa tertinggi.

Vijgen et al., (2011) menjelaskan bahwa penggunaan pestisida berdampak buruk terhadap kesehatan hewan dan manusia. Endosulfan merupakan insektisida paling beracun yang tersedia di pasaran saat ini dan telah menyebabkan berbagai macam keracunan pestisida yang fatal pada manusia dan hewan di seluruh dunia. Zat ini dapat masuk kedalam tubuh melalui traktus intestinal, paru-paru, dan kulit serta telah terbukti memiliki efek toksik pada berbagai organ seperti otak, jantung, organ reproduksi, ginjal dan hepar (Andarini dkk., 2013).

Hepar memiliki peranan yang sentral dalam metabolisme bahan toksik yang ada di dalam tubuh (Fawcett, 2002). Kerusakan pada hepatosit menyebabkan 
terjadinya perubahan struktur sel, yang berakibat terjadinya gangguan fungsi sel. Hepatosit yang mengalami kerusakan struktur mengakibatkan gangguan dalam metabolisme (Graham and Guarrera, 2014).

Oleh karena itu, perlu dilakukan penelitian ini untuk mengetahui pengaruh Endosulfan terhadap perubahan histopatologi hepar.

\section{METODE PENELITIAN}

Penelitian ini dilaksanakan pada bulan November 2014. Penelitian ini dilaksanakan di Kandang Hewan Coba, Laboratorium Patologi Veteriner Fakultas Kedokteran Hewan Universitas Airlangga Surabaya. Hewan coba dibagi dalam 4 kelompok perlakuan. Kelompok perlakuan dibuat sebagai berikut: P0 tanpa diberi Endosulfan hanya pemberian aquadest, P1 pemberian Endosulfan sebanyak 6,25mg/Kk BB, P2 pemberian Endosulfan sebanyak 12,5mg/Kk BB, P3 pemberian Endosulfan sebanyak 25mg/Kk BB.
Pemberian Endosulfan setelah masa adaptasi selama tujuh hari. Pemberian Endosulfan dilakukan satu kali pada hari ke-8 karena menggunakan sigle dose. Pengumpulan sampel dilakukan dengan cara bedah bangkai untuk mengambil sampel hepar dan dimasukkan de dalam pot toples. Pembuatan sediaan histopatologi dilakukan di Laboratorium Patologi Departemen Patologi Veteriner Fakultas Kedokteran Hewan Universitas Airlangga.

Pengamatan dilakukan dengan menggunakan metode scoring (Brunt, 2000). Data yang diperoleh merupakan nilai median dan modus dari empat lapangan pandang dari masing-masing preparat.

\section{HASIL DAN PEMBAHASAN}

Hasil penelitian tentang Pengaruh Endosulfan Terhadap Perubahan Histopatologi Hepar Mencit (Mus musculus) berdasarkan skor kerusakan sel hepar dengan perubahan keradangan, degenerasi dan nekrosis yang dianalisis 
data dengan Kruskal Wallis menunjukkan perbedaan antar perlakuan $\mathrm{p}<0,05$ dilanjutkan dengan pengolahan data lebih lanjut dengan uji Mann Whitney. Hasil median dan modus pengamatan scoring radang, degenerasi dan nekrosis disajikan seperti pada Tabel (2,3 dan 4). Hasil pengamatan histopatologi hepar disajikan pada gambar (1), (2), dan (3).

\section{Tabel 1 Scoring Kerusakan Radang, Degenerasi dan Nekrosis}

\begin{tabular}{ll}
\hline Score & Radang \\
\hline 0 & Apabila tidak ada perubahan radang hepar \\
1 & Perubahan radang ringan seluas $<1 / 3$ lapangan pandang \\
3 & Perubahan radang sedang seluas 1/s3 - 2/3 lapangan pandang \\
4 & Perubahan radang berat seluas $>2 / 3$ lapangan pandang \\
\hline Score & Degenerasi \\
\hline 0 & Apabila tidak ada perubahan degenerasi hepar \\
1 & Perubahan degenerasi ringan seluas $<1 / 3$ lapangan pandang \\
3 & Perubahan degenerasi sedang seluas $1 / 3-2 / 3$ lapangan pandang \\
4 & Perubahan degenerasi berat seluas $>2 / 3$ lapangan pandang \\
\hline Score & Nekrosis \\
\hline 0 & Apabila tidak ada perubahan nekrosis hepar \\
1 & Perubahan nekrosis ringan seluas $<1 / 3$ lapangan pandang \\
3 & Perubahan nekrosis sedang seluas 1/3 - 2/3 lapangan pandang \\
4 & Perubahan nekrosis berat seluas $>2 / 3$ lapangan pandang
\end{tabular}

Tabel 2 Nilai Median dan Modus Radang Hepar Mencit

\begin{tabular}{lll}
\hline Kelompok Perlakuan & Median & Modus \\
\hline P0 & $0,00^{\mathrm{a}}$ & 0
\end{tabular}




$\begin{array}{lll}\text { P1 } & 1.00^{\mathrm{b}} & 1 \\ \text { P2 } & 1,50^{\mathrm{c}} & 1 \\ \text { P3 } & 1,50^{\mathrm{c}} & 1\end{array}$

Tabel 3 Nilai Median dan Modus Degenerasi Hepar Mencit

\begin{tabular}{|c|c|c|}
\hline Kelompok Perlakuan & Median & Modus \\
\hline P0 & $0,00^{\mathrm{a}}$ & 0 \\
\hline P1 & $1,25^{b}$ & 1 \\
\hline P2 & $2,50^{c}$ & 3 \\
\hline P3 & $4,00^{c}$ & 4 \\
\hline
\end{tabular}

Tabel 4 Nilai Median dan Modus Nekrosis Hepar Mencit

\begin{tabular}{lll}
\hline Kelompok Perlakuan & Median & Modus \\
\hline P0 & $0,00^{\mathrm{a}}$ & 0 \\
P1 & $0.50^{\mathrm{b}}$ & 0 \\
P2 & $2,00^{c}$ & 1 \\
P3 & $4,00^{c}$ & 4
\end{tabular}

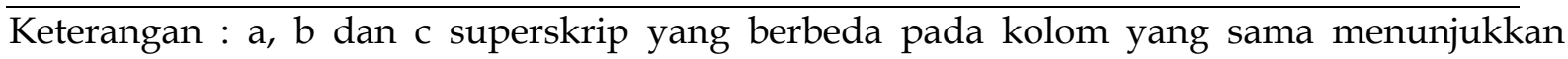
perbedaan yang signifikan $(\mathrm{p}<0,05)$.

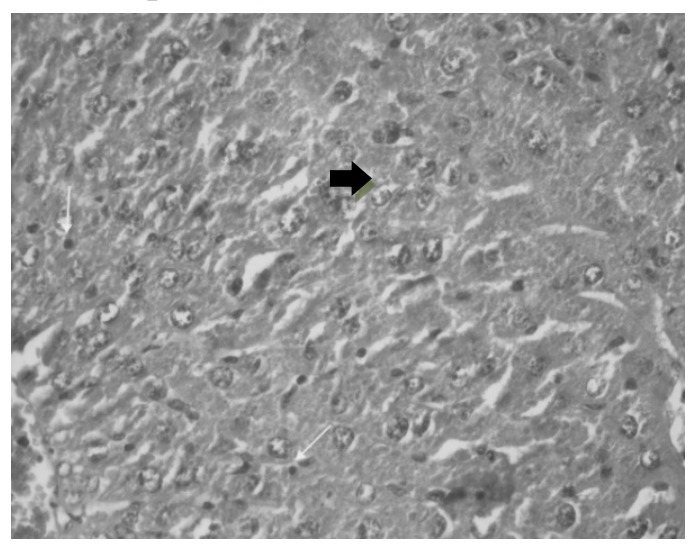

Gambar 1. Histopatologi Hepar Mencit yang Mengalami Radang (Pewarnaan H.E Perbesaran 400x) 
Berdasarkan hasil analisis statistik untuk radang hepar dengan uji Kruskal Wallis menunjukkan bahwa terdapat hasil yang berbeda nyata $(p<0,05)$. Pada uji
Mann Whitney didapatkan P0 berbeda nyata dengan $\mathrm{P} 1, \mathrm{P} 2, \mathrm{P} 3$ dan $\mathrm{P} 1, \mathrm{P} 2, \mathrm{P} 3$ tidak berbeda nyata.

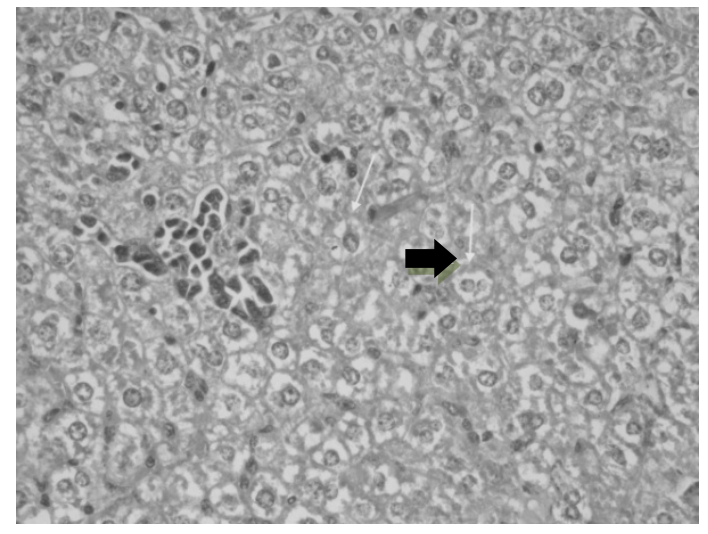

\section{Gambar 2.Histopatologi Hepar Mencit yang Mengalami Degenerasi} $(\Rightarrow$ (Pewarnaan H.E Perbesaran 400x)

Berdasarkan hasil analisis statistik $\quad(p<0,05)$. Pada uji Mann Whitney untuk radang hepar dengan uji Kruskal didapatkan P0 berbeda nyata dengan P1, Wallis (lampiran 5) menunjukkan bahwa P2, P3. P1 berbeda nyata dengan P2 dan terdapat hasil yang berbeda nyata P2 dengan P3 tidak berbeda nyata.

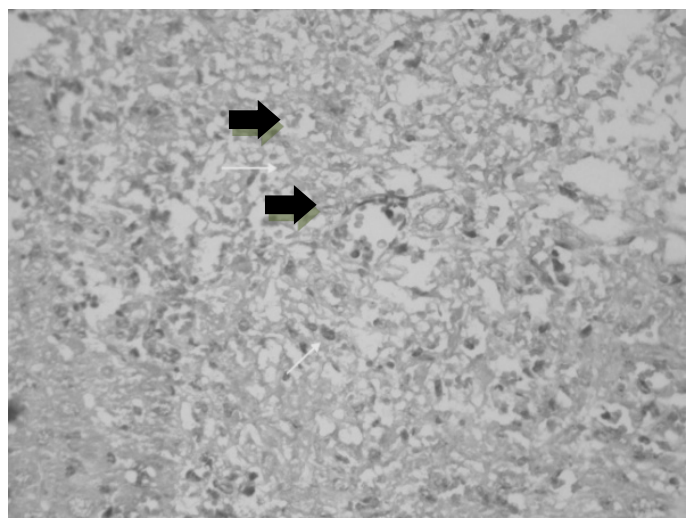

Gambar 3.Histopatologi Hepar Mencit yang Mengalami Nekrosis (Pewarnaan H.E Perbesaran 400x) 
Berdasarkan hasil analisis statistik untuk radang hepar dengan uji Kruskal Wallis menunjukkan bahwa terdapat hasil yang berbeda nyata $(p<0,05)$. Pada uji Mann Whitney didapatkan P0 berbeda nyata dengan P1, P2, P3. P1 berbeda nyata dengan P2 dan P2 dengan P3 tidak berbeda nyata.

Kelompok perlakuan P0 yaitu tanpa diberikan Endosulfan hanya diberi aquadest, kondisi hepar normal sel hepar tidak mengalami jejas. Kelompok perlakuan P1, P2 dan P3 pemberian Endosulfan dengan dosis berbeda menunjukkan kelainan patologi radang dengan skor 1, karena radang merupakan reaksi pertahanan diri suatu organ sebagai respon terhadap cedera berupa reaksi vaskular akibat zat toksik yang masuk ke dalam tubuh (Arimbi dkk., 2013).Kelompok P1 pemberian Endosulfan paling kecil mengalami sedikit perubahan degenerasi. Hal tersebut sesuai dengan pernyataan Junqueria dan Cameiro (2012) bahwa hepatosit yang mengalami jejas ringan akan mudah meregenerasi akibat zat-zat toksik yang masuk ke dalam tubuh. Kelompok P2 mengalami perubahan degenerasi sedang, karena menurut penelitian Khofiyah (2014) sifat dari degenerasi yaitu reversible sehingga pemberian dosis tertentu masih dapat mengalami degenerasi tetapi tidak parah sehingga dapat regenerasi baru pada hepatosit. Keparahan degenerasi terlihat pada kelompok P3 dapat disebabkan karena dosis yang tinggi sehingga menghambat peredaran darah menuju jantung serta perusakan sistem saraf utama pada otak karena sifat dari golongan organoklorin menimbulkan mekanisme kerja terutama pada akson saraf dan jaringan lemak, segera didistribusi dan terakumulasi di kandung empedu dalam bentuk Chlordecon. Sehingga dapat memicu stress disertai imunitas menurun dan cedera sel lebih banyak (Kneeman, 2012). Pada penelitian Bawaningrum dkk. (2014) tentang desinfektan Didecy Dimethylammonium 
Cloride jejas akibat toksik biasanya diawali dengan degenerasi dengan pemberian lima hari sudah terlihat perubahan histopatologi berupa degenerasi.Kelompok P0 dan kelompok P1 berbeda nyata tetapi memiliki modus yang sama sehingga kelompok P0 dan kelompok P1 tidak ditemukannya nekrosis karena menurut penelitian Bawaningrum dkk. (2014) dibutuhkan waktu lebih dari lima hari untuk terjadi nekrosis karena dengan dosis yang kecil belum berarti mengakibatkan perubahan atau kematian inti sel pada hepar sehingga hanya ditemukan degenerasi. Kelompok P2 terdapat nekrosis ringan. Penggunaan dosis 15mg/Kk BB dapat mengakibatkan nekrosis dikarenakan dapat meningkatkan apoptosis pada inti hepatosit, karena apoptosis adalah salah satu perubahan inti hepatosit yang menandakan bahwa terjadi nekrosis selain karioreksis dan kariolisis (Ozmen, 2003). Kelompok P3 dengan dosis 25mg/Kg BB mengalami nekrosis paling berat diantara kelompok lain. Pada laporan POPs Elimination Network (2009) dengan dosis $35 \mathrm{mg} / \mathrm{Kg} \quad \mathrm{BB}$ dapat mematikan pada manusia, karena Endosulfan menyerang sistem jaringan saraf terutama pada otak yang menghambat transpor kalium melalui membran sel, menghambat transpor aktif natrium keluar sel, menghambat kalsium, menghambat kemampuan kalmodulin sebagai kalsium mediator. Akibat yang ditimbulkan terjadi perpanjangan aksi potensial sampai terjadi hiperpolarisasi. Berpengaruh pada jaringan lemak, terjadi biomagnifikasi yaitu penimbunan senyawa yang bersifat permanen (Meles dkk., 2012).

\section{KESIMPULAN}

Berdasarkan hasil penelitian histopatologi mencit yang dipapar Endosulfan dapat ditarik kesimpulan bahwa pemberian Endosulfan pada mencit berpengaruh terhadap histopatologi hepar mencit yaitu terjadi infiltrasi radang, degenerasi dan nekrosis. Semakin tinggi dosis perubahan histopatologi hepar mencit semakin parah. 
DAFTAR PUSTAKA

Adhiraga, M. 2009. Profil Penyebaran Konsentrasi Pestisida Organoklorin pada Air Sungai Subdas Citarum Hulu [Thesis]. Institut Teknologi Bandung. Bandung.

Andarini, S., H. Sjuti dan F. Ariadi. 2013. Pengaruh Endosulfan Terhadap Peningkatan Kadar 1L-6 Serum pada Anak Tikus Strain Wistar (Rattus norvegincus) [Skripsi]. Program Studi Pendidikan Kedokteran Fakultas Kedokteran. Universitas Brawijaya. Malang.

Arimbi., A. Azmijah., R. Darsono., H. Plumeriastti., T. V. Widiyatno dan J. Legowo. 2013. Buku Ajar Patologi Umum Veteriner. Airlangga University Press. Surabaya.

Bawaningrum, C. R., E. Koestanti dan C. Anwar. 2014. Pengaruh Pemberian Desinfektan Didecydimethyl ammonium Chloride Terhadap Gambaran Histopatologi Hepar pada Bebek Hibrida (Anas Platyrhynchos Domesticus). Fakultas Kedokteran Hewan. Universitas Airlangga Surabaya. Surabaya.

Fawcett, D.W. 2002. Buku Ajar Histologi. Ed 12. EGC. Jakarta. 583-603.

Graham, J. A. and J. Guarrera. 2014. Resucitation of Marginal Liver Allografts for Transplantation with Machine Perfution Technology. Department of Surgery. Colombia University. USA. 1-14.

International POPs Elimination Network. 2009. Endosulfan in West Africa Adverse Effects its Banning and Alternatives. POPs Pesticides Working Group. Africa.

Khofiyah, S. N. 2014. Efek Pemberian Ekstrak Ethanol Daun Kenikir (Cosmos caudatus) Terhadap Gambaran Histopatologis Hepar pada Mencit (Mus musculus) Babb/C Jantan yang Diinduksi Parasetamol. Fakultas Kedokteran Hewan. 
Universitas Airlangga Surabaya.

Surabaya.

Kneeman, J. M., J. Misdraji and K.E.

Korey. 2012. Secondary Causes Of

Nodalcoholic Fatty Liver Disease.

Department of Pathology

Massachusetts General Hospital and

Harvard Medical School. Bostom.

SA 199-207.

Meles, D. K., S. A. Sutjarwo., T. Juniastuti.,

I. S. Hamid dan R. Kurnijasanti.

2012. Buku Ajar Farmakoterapi dan

Toksikologi. Pusat Penerbitan dan

Percetakan Universitas Airlangga

(AUP). Surabaya.

Ozmen, O. 2003. Pathology of Endosulfan.

University of Mehmet Akif Ersoy.

Turkey.

Rocmanti dan M. Dian. 2009. Identifikasi

Penggunaan Pestisida pada Ladang

dan Sawah [Thesis]. Institut

Teknologi Bandung. Bandung.

Van den Berg, H. 2009. Global Status of

DDT and Its Alternatives for Use in
Vector Control to Prevent Disease. Health Persp. Environ. 117: 16561663.

Vijgen, J., P. C. Abhilash and Y. F. Li. 2011. Hexachlorocyclohexane $(\mathrm{HCH})$ as new Stockholm Convention POPs-a Global Perspective on the Management of Lin-dane and its Waste Isomers.. Sci. Pollut. Environ.

18: 152-162. 